\title{
THE "TAMBLA" (HUMUYA) GOMPHOTHERE (HONDURAS): THE FIRST REPORT OF FOSSIL VERTEBRATES IN CENTRALAMERICA
}

\author{
EL GONFOTERIO DE "TAMBLA" (HUMUYA, HONDURAS): EL PRIMER \\ REGISTRO DE UN VERTEBRADO FÓSIL EN AMÉRICA CENTRAL
}

Spencer G. Lucas ${ }^{1 *}$, Mark Bonta ${ }^{2}$, Robert Rogers ${ }^{3} \&$ Guillermo E. Alvarado ${ }^{4}$

${ }^{1}$ New Mexico Museum of Natural History and Science, 1801 Mountain Road N. W., Albuquerque, New Mexico 87104 USA

${ }^{2}$ Division of Social Sciences, Delta State University, Cleveland, Mississippi 38733 USA

${ }^{3}$ Department of Physics and Geology, California State University, Stanislaus, One University Circle, Turlock, California 94382

${ }^{4}$ Escuela Centroamericana de Geología, Universidad de Costa Rica, Apdo. 214, 2060, San José, Costa Rica

*Autor para contacto: spencer. lucas@state.nm.us

(Recibido: 15/02/2011; aceptado: 01/06/2011)

\begin{abstract}
In 1858, American geologist Joseph LeConte published the first scientific report of vertebrate fossils (mastodon, bison and horse) from Central America a brief record of a "mastodon bed" near the old village of Tambla in Honduras. In 1859, American archaeologist Ephraim George Squier also mentioned these fossils, illustrating a lower jaw fragment with a molar and providing specific clues to the location of the bonebed. J. M. Dow subsequently gave a gomphothere molar from the locality to Joseph Leidy at the Academy of Natural Sciences in Philadelphia, USA. Leidy published on the fossil, which still remains in the collection of the Academy, as "Mastodon ohioticus" or as M. andium, and it was later referred to Rhynchotherium by Osborn and others. This molar is best identified as Cuvieronius hyodon, and the bonebed from which it was derived is near the modern village of Humuya (Tambla in the 1800s), not near the village currently called Tambla. The Tambla "mastodon bed" has never been relocated, though data provided here should make that possible. Its discovery in the $1850 \mathrm{~s}$ did not encourage further exploration for vertebrate fossils in Honduras, probably because "mastodon" fossils were already commonplace in the USA, so the Tambla bonebed did not constitute a remarkable discovery.

Keywords: Honduras, Tambla, Humuya, gomphothere, mastodon
\end{abstract}




\begin{abstract}
RESUMEN: En 1858, el geólogo estadounidense Joseph LeConte publicó el primer reporte científico de una fósil vertebrado en América Central, registrado como una "capa de mastodonte" cerca del pueblo de Tambla en Honduras. En 1859, el arqueólogo estadounidense Ephraim George Squier también mencionó estos fósiles, ilustrando un fragmento de la mandíbula inferior con un molar y aportó las claves específicas de la localización de la capa de huesos. J.M. Dow subsecuentemente donó el molar de mastodonte a Joseph Leidy, de la Academia de Ciencias Naturales de Filadelfia, identificado como "Mastodon ohioticus" o como M. andium, y que fue más tarde referido como Rhynchotherium por Osborn y otros. Leidy publicó sobre el fósil, el cual todavía permanece en la colección de dicha academia. Así este molar es mejor identificado, al día de hoy, como un Cuvieronius hyodon, y la capa fosilífera del cual proviene se localiza cerca del rebautizado pueblo de Humuya (llamada Tambla en el siglo XIX), lejos del actual pueblo de Tambla. La "capa de mastodonte" de Tambla nunca ha sido relocalizada; por ello, los datos acá aportados deberían de hacerlo posible. Su descubrimiento en los mediados de la década de los cincuenta del siglo antepasado no motivó mayores exploraciones de fósiles de vertebrados en Honduras, quizás debido a que los mastodontes eran en ese entonces hallazgos frecuentes en EE.UU, así que la capa fosilífera de Tambla no constituyó un descubrimiento sobresaliente.
\end{abstract}

Palabras clave: Honduras, Tambla, Humuya, gonfoterio, mastodonte

\section{INTRODUCTION}

The fossil record of vertebrates in Central America encompasses hundreds of localities of late Cenozoic age. Most of these yield fossil mammals of Pleistocene age, and most of what we know about these fossils has been published since the 1980s (e. g., Ibarra, 1980; Webb \& Perrigo, 1984; Alvarado, 1986; Laurito, 1988; Lucas et al., 1997, 2007, 2008; Cisneros, 2005, 2008; MacFadden, 2006; Lucas \& Alvarado, 2010; Woodburne, 2010). These fossils are particularly significant to documenting the great American interchange - the extensive mixing of North and South American mammals that took place via Central America after the Panamanian isthmus closed during the Pliocene (Woodburne, 2010). Discoveries of fossil vertebrates (mammals) in Central America began in the 1800s and initiated our current knowledge of a diversity of MiocenePleistocene taxa (Alvarado, 1994). Here, we detail the first discovery of fossil mammals in Central America (cf. Alvarado, 1994, p. 82), that of gomphothere proboscidean fossils near “Tambla," Honduras (Fig. 1).

\section{LECONTE AT TAMBLA}

LeConte (1858) presented the first published mention of a fossil vertebrate from Central America. Joseph LeConte (1823-1901) was an American geologist who visited Honduras in 1858 while he was a professor at South Carolina College in the USA. LeConte (1858) presented a brief account of proboscidean fossil he encountered in Honduras to the Academy of Natural Sciences in Philadelphia during its meeting of February 2, 1858:

Dr. LeConte said that while he was recently in Honduras, he had examined the Mastodon bed at the village of Tambla, in one of the passes leading from Comayagua to the Pacific. He was satisfied of the identity of the remains with $\mathrm{M}$. [Mastodon] giganteus. He had found there a molar of Bos and two or three of Equus (LeConte, 1858, p. 7).

Significantly, LeConte refers to "the Mastodon bed," as if it were an already known location, and mentions finding "Bos" (if fossil, should be Bison) and horse (Equus) at the bed. We know of no fossils in collections (for example, the Academy of Natural Sciences of Philadelphia) that voucher LeConte's identifications, but if correct they suggest a late Pleistocene (Rancholabrean) age for the bone bed near Tambla.

\section{SQUIER AT TAMBLA}

Ephraim George Squier (1821-1888) was an American journalist and diplomat (Fig. 2). As an amateur archaeologist, he began in the 1840 s to collaborate with another amateur, Edwin Davis (1811-1887) on the study of Native 


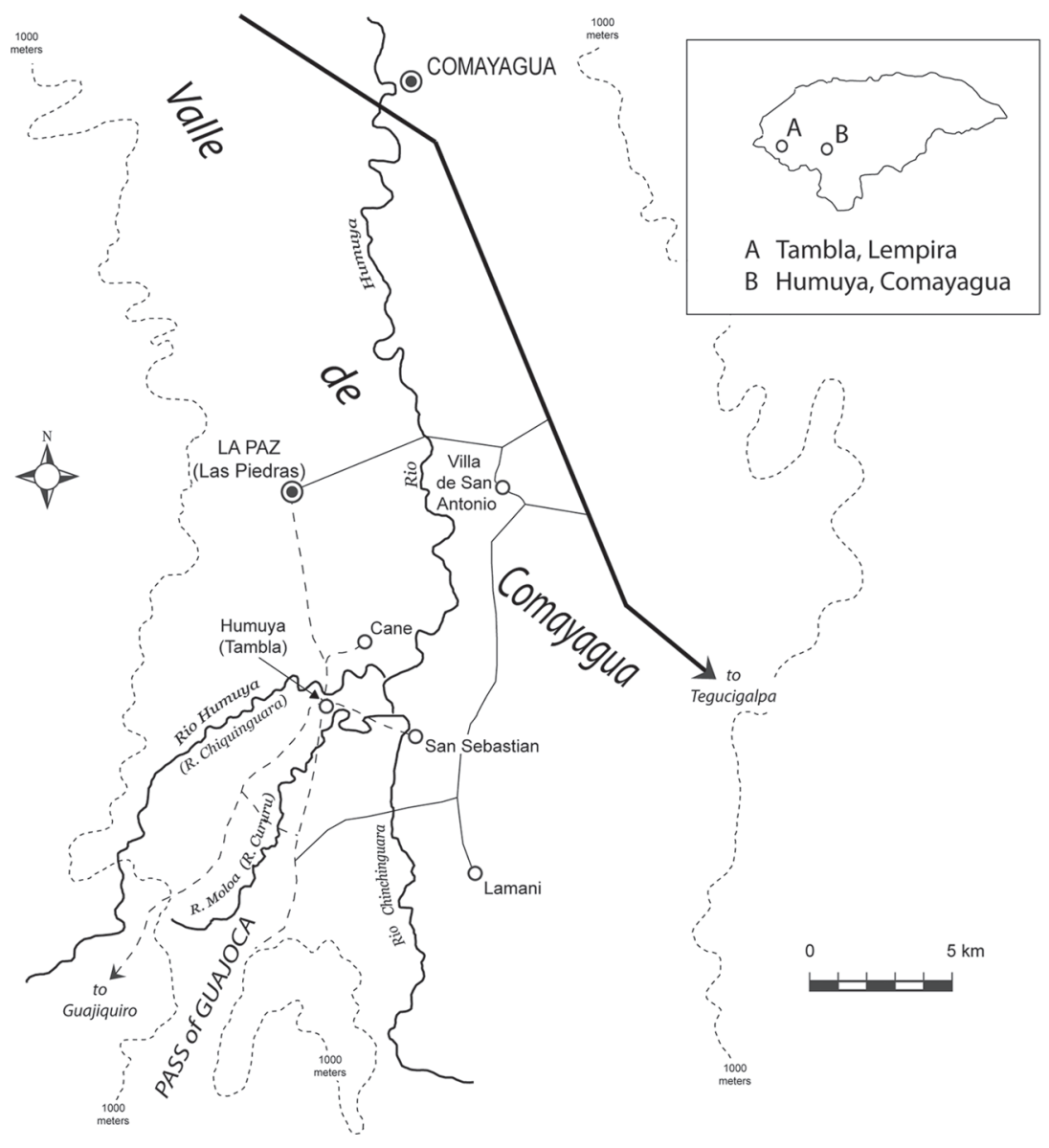

Fig. 1: Map of the Valle de Comayagua area in Honduras, showing location modern Humuya (Tambla village until 1897). Insert is a map of Honduras with the modern localities of Tambla and Humuya.

American mound builders in the Mississippi Valley, especially in Ohio, USA. The book on the mound builders published by Squier and Davis in 1848 established Squier as an important American archaeologist. To both support himself financially (publication of the book with Davis left Squier destitute) and to continue his pursuit of archaeology, Squier sought a diplomatic post in Central America, in order to study the rich archaeology of that region. In April 1849, helped by the influence of powerful friends in Washington, Squier was appointed "Charge d'Affaires of the United States to the Republics of Central America" and assumed that post in Nicaragua, holding it for about one year. After his diplomatic mission ended, Squier remained in Central America and became the secretary of the Honduras Interoceanic Railway Company. He subsequently published important contributionsto knowledge of the archaeology, ethnography and geography of Central America, especially Honduras, El Salvador and Nicaragua (Barnhart, 2005).

Squier wrote at least three unsigned articles on Central America for Harper's New Monthly Magazine, including "San Juan de Nicaragua" (1854), "A Visit to the Guajiquero Indians "(1859), and "The Volcanoes of Central America" (1859). His only signed article on Central America was "Nicaragua: An Exploration from 


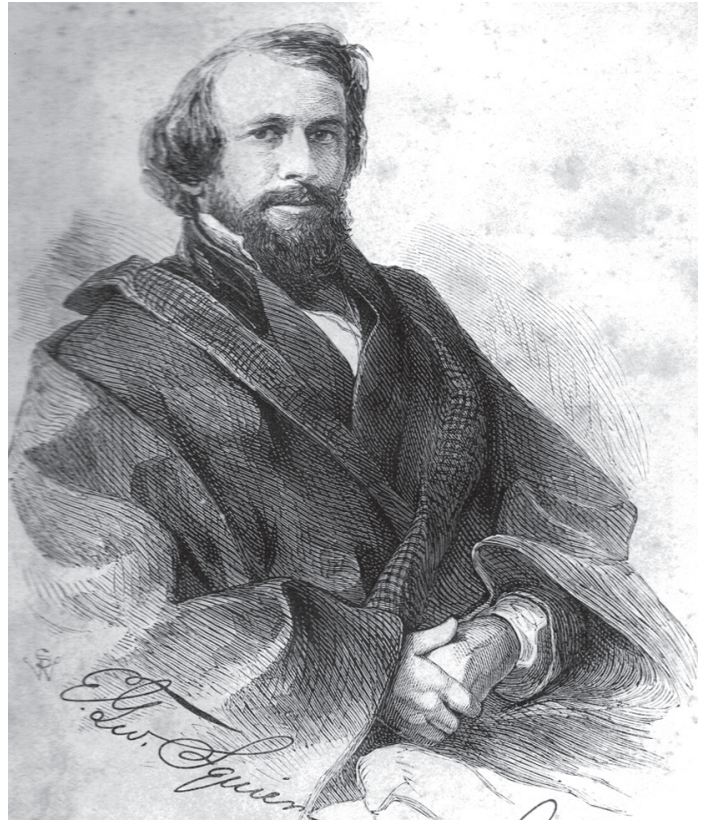

Fig. 2: Ephraim George Squier (1821-1888).

Ocean to Ocean" (1855).. Barnhart (2005) attributes the article on the Guajiquero Indians of Honduras to Squier, and, in it, Squier, (1859, p. 610) referred to the "mastodon" bones near Tambla and provided the first illustration of a fossil from the locality (Fig 3):

The huesos grandes, or big-bones, of which we had heard, occur about a league from Tambla, in a sandstone formation, and consist of a large deposit of the fossilized bones of the mastodon. They are not simply the remains of a single skeleton, but of several, and are well worthy of the study of naturalists. We carried away a single tooth as a trophy, regretting only that our limited means of transport did not enable us to contribute more largely to the collections illustrative of natural history of which our country may so justly boast.

Barnhart (2005) places Squier studying the Guajiquero Indians near Tambla in June of 1853, which became the basis of his 1859 article. It thus seems certain that Squier knew about the fossils near Tambla before LeConte, though his published report appeared later.

\section{LEIDY AND THE TAMBLA MOLAR}

Joseph Leidy (1823-1891) (Fig. 4) is considered the father of American vertebrate paleontology and was a professor at the University of Pennsylvania and a Curator at the Academy of Natural Sciences in Philadelphia (Warren, 1998). Because of his expertise in vertebrate anatomy and paleontology, fossils from many locations were sent to Leidy for study. Thus, Leidy $(1859$, p. 91) announced receiving a single molar of a gomphothere proboscidean from Tambla at the 22 March 1859 meeting of the Academy of Natural Sciences in Philadelphia, stating that "Dr. Leidy called the attention of the members to the tooth of the Mastodon, from Tambla, Honduras, presented by Capt. J. M. Dow, this evening." This tooth, which we term the "Tambla molar," is the only fossil from the Tambla fossil locality now extant in a collection--it is catalogued in the collection of the Academy of Natural Sciences of Philadelphia (see below). Leidy's (1859, p. 91) report went on to conclude that the Tambla molar "probably belongs to the species "Mastodon ohioticus."

John Melmouth Dow (1827-1892) was an American shipmaster, shipping agent and naturalist who first went to the Central American coast in 1851 and worked there in association with the Panama Railroad Company (Udovic et al., 1974).

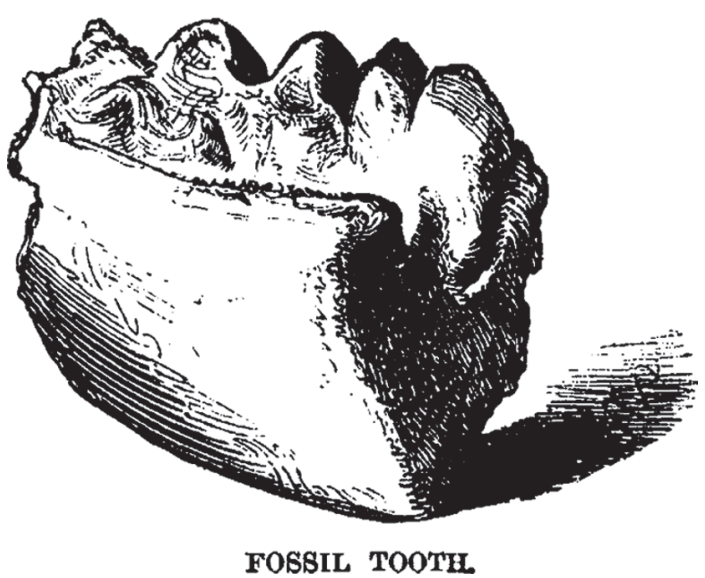

Fig. 3: Drawing of a lower jaw fragment with molar of a "mastodon" collected near Tambla (from Squier, 1859, p. 610). 


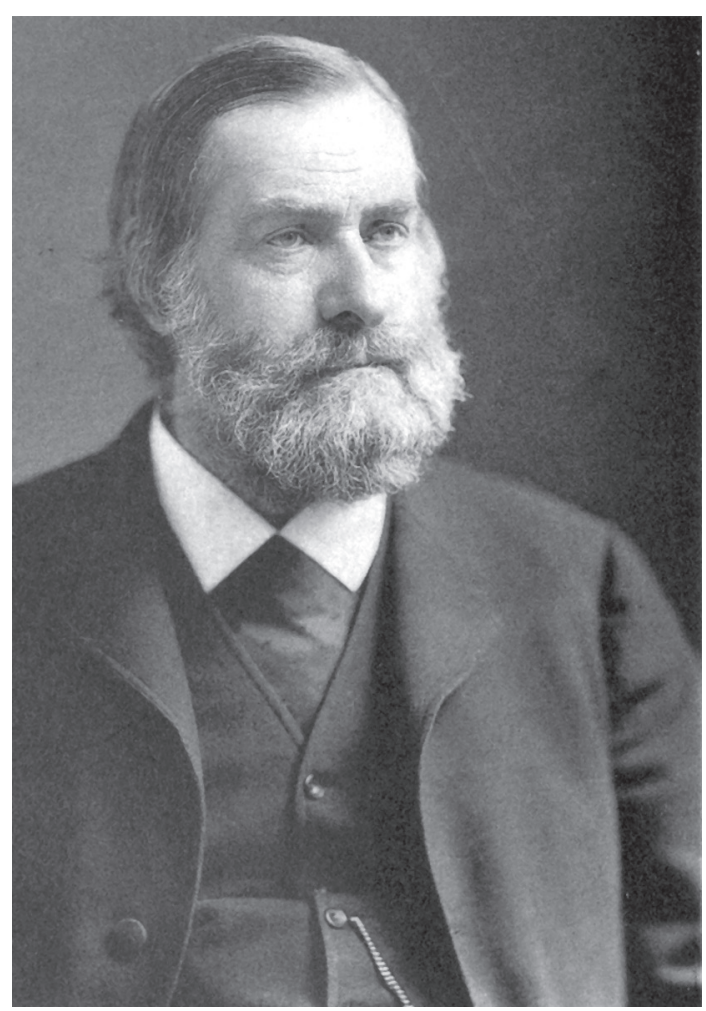

Fig. 4: Joseph Leidy (1823-1891).

He remained involved in the coastal trade of Central and South America until 1876 and also worked for the Panama Railroad Company. Dow's activities as a naturalist focused on collecting extant fishes, and catalogues and information about his collections were published by various authorities. Dow was also a correspondent of the Academy of Natural Sciences in Philadelphia. How Dow acquired the Tambla molar is unknown; perhaps it was the "single tooth as a trophy" that Squier (1859, p. 610) says he collected, but we know of no way to confirm this possibility. Dow's association with the Academy of Natural Sciences and with Leidy no doubt led him to donate the molar to the Academy.

In his classic monograph on the fossil mammals of the Dakota and Nebraska territories, Leidy (1869, p. 242-243, pl. 27, fig. 14) described and illustrated the proboscidean molar from Tambla (Fig. 5A). Leidy (1869, p. 240) stated that "perhaps the Mastodon andium is indicated by a molar tooth, obtained at Tambla, Honduras, by Capt. J. M. Dow, and presented by him to the Academy." Leidy (1869, p. 242-243) based this tentative identification on the similarity of the Tambla molar to a molar of $M$. andium from Tarija, Bolivia described and illustrated by Gervais (1855, p. 20, pl. 5, fig. 3). In current taxonomy, the gomphothere from Tarija would be identified as Cuvieronius hyodon (Lucas, 2008a, b; Ferretti, 2008).

\section{THE TAMBLA MOLAR AS RHYNCHOTHERIUM}

In describing proboscidean fossils from the Valley of Mexico, Edward Drinker Cope (1884, p. 7) referred to the Tambla molar, allying it to the taxon he called "Dibelodon shepardi," a species later referred to Rhynchotherium by various authors, but now regarded as a nomen dubium based on undiagnostic type material (Lucas \& Morgan, 2008). Indeed, in his comprehensive monograph on the Proboscidea, Henry Fairfield Osborn (1936, p. 482) referred to the Tambla molar illustrated by Leidy (1869) as "certainly a member of the Rhynchorostrinae and allied to Rhynchotherium browni of Sonora. " Osborn (1936, fig. 454C) illustrated the molar as Rhynchotherium (Fig. 5B) and also stated (p. 535) that it is "more primitive than Rhynchotherium falconeri...it resembles $R$. browni of Sonora, Mexico." Laurito \& Valerio (2005) also mentioned the Tambla molar as Rhynchotherium.

\section{IDENTIFICATION OF THE TAMBLA MOLAR}

The Tambla molar (Fig. 6), catalogued as ANSP (Academy of Natural Sciences of Philadelphia) 13349 , is a left lower third molar (m3) that has a maximum crown length of $152 \mathrm{~mm}$ and a maximum crown width of $79.5 \mathrm{~mm}$. It has four lophids, single trefoils, a relatively low crown and ptychodont enamel. The tooth is moderately 

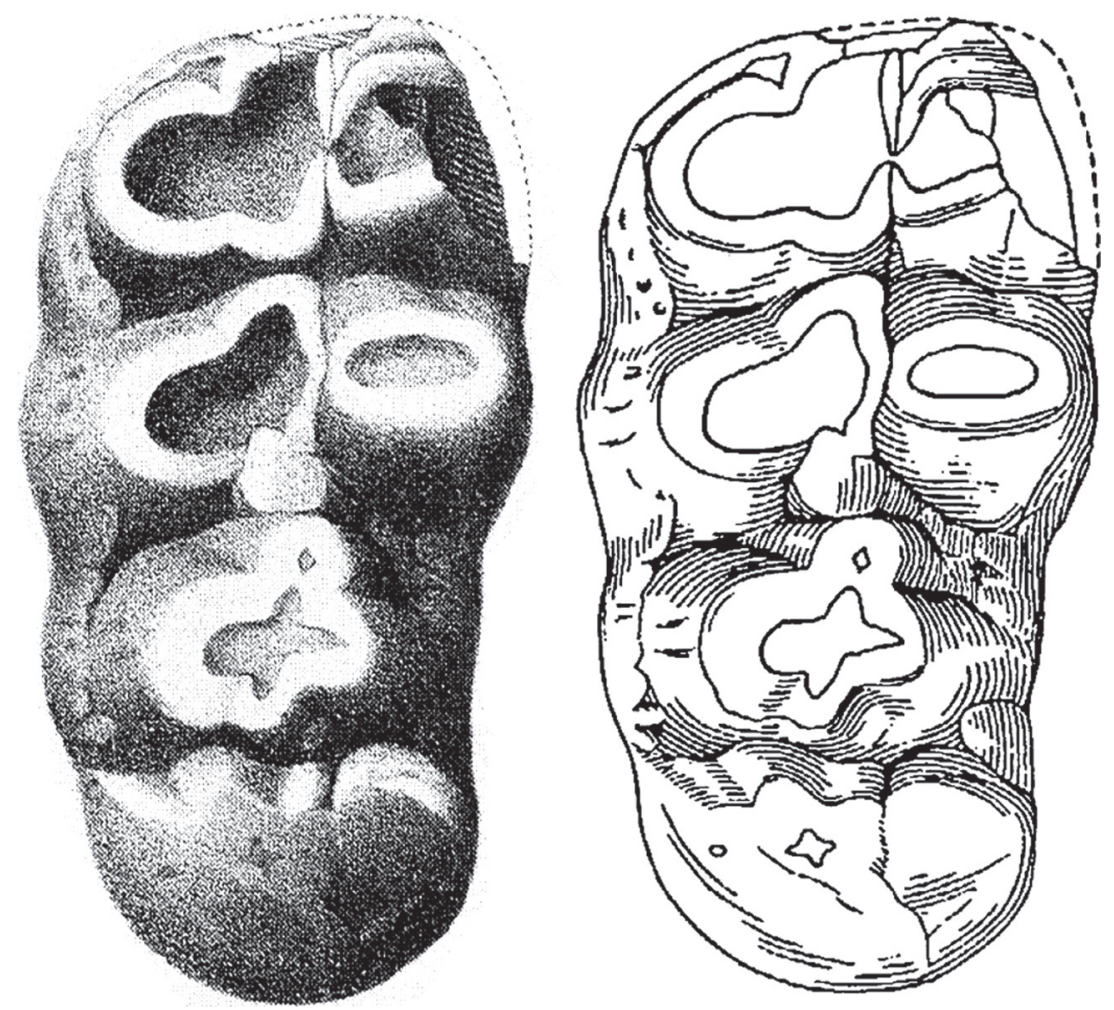

Fig. 5: Illustrations of the Tambla "mastodon" molar in occlusal view, ANSP 13349. A, From Leidy (1869, pl. 27, fig. 14). B, From Osborn (1936, fig. 454C). Total length of the molar crown is $152 \mathrm{~mm}$.

worn, so that dentine is exposed across the first three lophids, and it has a distinct labial cingulid.

The "mastodon" fossils from Tambla have been assigned a variety of taxonomic names: Mastodon giganteus by Le Conte (1858), Mastodon ohioticus by Leidy (1859), Mastodon (= Haplomastodon) andium by Leidy (1869), Dibelodon shepardi by Cope (1884), Rhynchotherium by Osborn (1936) and Laurito \& Valerio (2005), and Cuvieronius hyodon by Lucas et al. (2007). The relatively bunodont crown with trefoils excludes identification as "Mastodon" (= Mammut in North American usage), and the isolated tooth cannot be assigned with certainty to either Haplomastodon, Rhynchotherium or Cuvieronius (cf. Lucas, 2008a; Lucas \& Morgan, 2008). Given that Haplomastodon and Rhynchotherium are not otherwise known from Central America (Lucas \& Alvarado, 2010), and if we accept in the probable determination of Bison (see previously comment based on LeConte, 1858), indicating a Pleistocene age (in apparent agreement with the regional geology briefly describe below), it seems most parsimonious to assign the Tambla molar to Cuvieronius, which is the most common Pleistocene gomphothere known from Central America (Fig. 7).

\section{LOCATION OF THE TAMBLA GOMPHOTHERE BONEBED}

On current maps of Honduras, Tambla is a town located in the Department of Lempira in western Honduras $\left(14^{\circ} 12^{\prime} \mathrm{N}, 88^{\circ} 43^{\prime} \mathrm{W}\right)$. Indeed, University of Florida paleontologist David Webb attempted to locate the Tambla fossil locality near that village, stating that in 1969 he "visited that remote village in the hope of finding further fossils, but no leads 


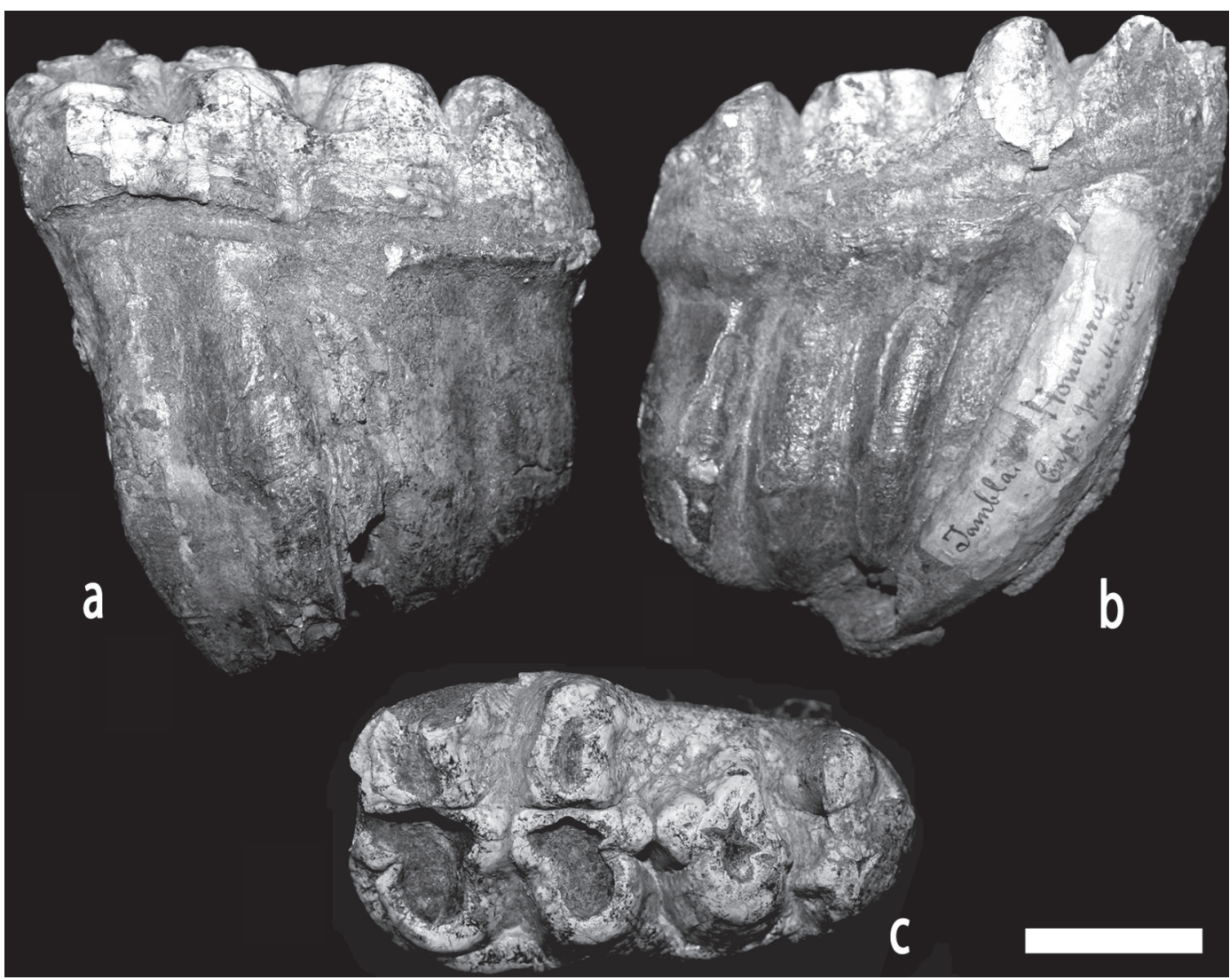

Fig. 6: The Tambla "mastodon" molar, ANSP 13349, here identified as a left m3 of Cuvieronius hyodon, in labial (A), lingual (B) and occlusal (C) views. Scale bar is $5 \mathrm{~cm}$ long.

nor even promising sediments within the ignimbrite mass were discovered. Presumably the 'Tambla Mastodon' came from a limited Pleistocene deposit in that area" (Webb \& Perrigo, 1984, p. 238).

The actual location of the Tambla being referred to by LeConte, Dow, Leidy and Squier in the 1850 s is much different. It is in the Comayagua Valley, and is modern Humuya, a village on the lower Río Cururú in the department of Comayagua, $120 \mathrm{~km}$ east of Tambla, Lempira (Fig. 1). Squier's map of his expedition reveals that (Fig. 8). In fact, the village of Tambla changed its name to the municipality of Humuya (also known as Humaya) after January 26, 1897, while contemporaneously, the former village of Tomalá in Lempira changed its name to the municipality of Tambla on September 11, 1896. The Río Chiquinguara is now the Río Humuya. Thus, it is easy to understand the confusion and mistake of Webb \& Perrigo (1984) as to the location of the fossil site.

Squier's (1859) account of the bonebed can also be used to determine its more precise location. Thus, on the first day of his visit to Guajiquiro (in the present-day department of La Paz), Squier visited the ruins of Yarumela and ended at the town of La Paz (also called Las Piedras), which is on the west side of the Comayagua Valley. The following morning, he and his companions were on horseback at dawn and arrived at the fossil locality by breakfast, thus probably riding for no more than three hours. After that, they continued to Guajiquiro, though it is not clear if the bone locality was off the main trail from La Paz to Guajiquiro. Squier (1859, p. 610-611) describes the trip after the bonebed as "a simple scramble up the mountains" and notes that "the temperature became sensibly cooler." We take 


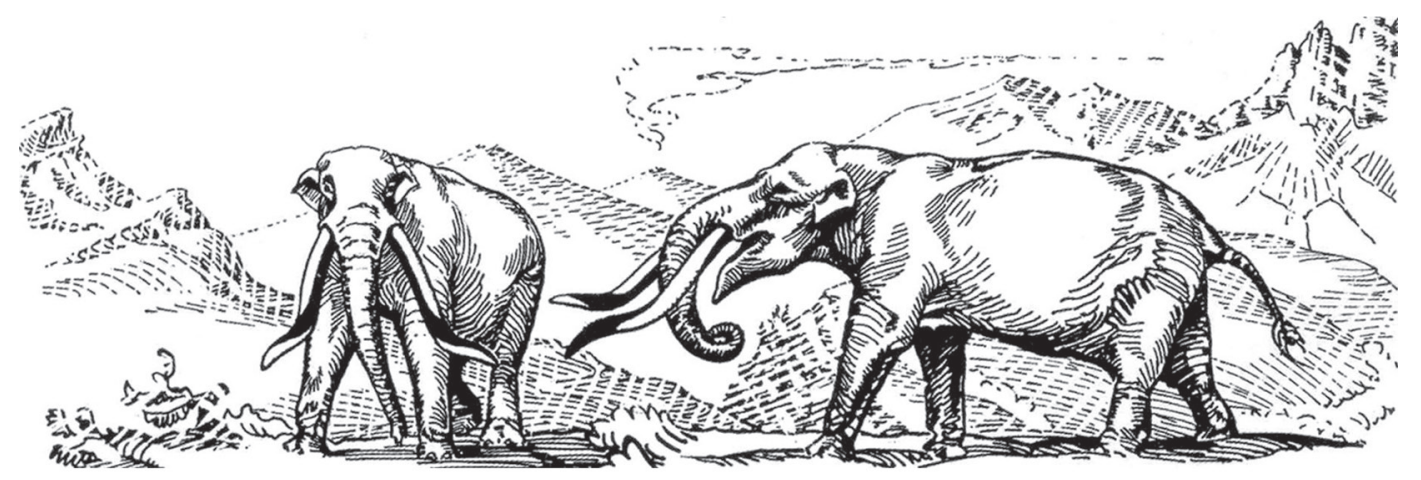

Fig. 7: The common Central American Pleistocene gomphothere Cuvieronius hyodon (from Osborn, 1936)

this as a strong clue that the bonebed itself is below 1000 meters in elevation.

Squier(1859) mentions the plain near the town of Tambla; clearly, the plain is the Comayagua Valley, so it seems likely that the bonebed was located on the edge of the plain, most likely on an alluvial fan at the base of a ridge. Pleistocene fossil bone localities are common in the Valle de Agalta in the department of Olancho (northeastern Honduras) in these types of areas, where streams have dissected the alluvium. Squier's (1859) statement that the bones were a league from Tambla seems misleading. Most likely, somebody in Tambla told him they were "una legua" and he wrote that down. This measurement can vary by several km. LeConte's (1858) reference to the bonebed being "in one of the passes leading from the plain of Comayagua to the Pacific," suggests that this is the "Pass of Guajoca," an extremely low pass on the way to the coast (Fig. 1). This indicates that the bonebed is southwest of modern Humuya, north of the Rio Moloa and south of the Río Humuya (Fig. 1). The sediments in this area are fluvial deposits (channel and overbank fines) mixed with a significant amount of ashfall tuffs. These fluvial strata, presumably of Quaternary age, overlie with angular unconformity the main beds of the mid-Miocene ignimbrite flare-up. Cursory exploration by one of us (RR) of this area, and inquiries of local residents, however, have so far not turned up a fossil bonebed.

\section{CONCLUSION}

What remains from this historical review of the discovery of gomphothere fossils near Tambla in the 1850 s is a mystery---where is the "mastodon bed" (LeConte, 1858, p. 7) near the village of Tambla? In the $1850 \mathrm{~s}$ at least three naturalists who visited Tambla were aware of an assemblage of proboscidean and other fossils located near the village. Rediscovery of this important fossil deposit should be pursued.

Perhaps a smaller mystery is why has there been no attempt to relocate the Tambla bonebed other than the misguided effort of Webb in 1969. In other words, why didn't the discovery of vertebrate fossils in Honduras during the 1850s lead to further exploration, or even a "bone rush," much as happened in the American West at about the same time? We think the answer to this question lies partly in the remote and challenging terrain that Central America posed to the fossil hunters of the late $1800 \mathrm{~s}$. In addition, by the 1850 s fossils of "mastodon" were common in the USA, having been some of the first fossils recognized in North America (e.g., Thomson, 2008). The discovery of "mastodon" fossils in Honduras during the 1850 s was thus merely another record of what were by then known to be common fossils, not an exciting discovery that drove further exploration. 


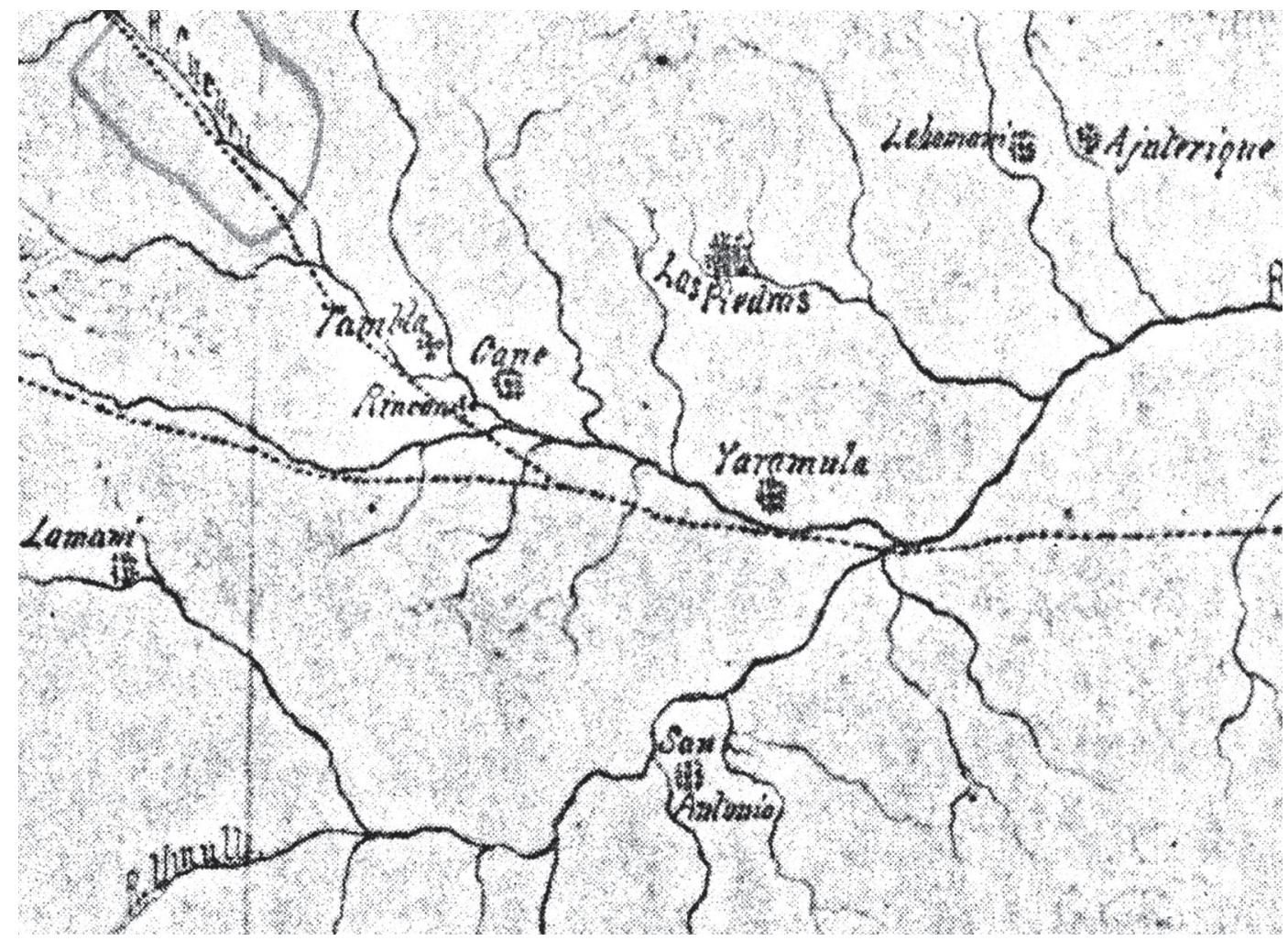

Fig. 8: Squier's map of the Tambla area (modified from Hébert, 1972). This is a portion of map no. 20 in the Squier Map Collection in the Geography and Map Division of the U. S. Library of Congress. According to Hébert (1972: 20) it is a pen and ink drawing at the scale of 1:200,000, probably completed in 1853

\section{ACKNOWLEDGMENTS}

Ted Daeschler and Ned Gilmore allowed access to the ANSP fossil collection. William Davidson provided helpful insight into the 1850 s location of Tambla in Honduras.

\section{REFERENCES}

ALVARADO, G.E. 1986: Hallazgos de megamammíferos fósiles de Costa Rica.Rev. Geol. Amér. Central, 4: 1-46.

ALVARADO, G.E., 1994: Historia Natural Antigua.232 págs., Cartago, Ed. Tec. de Costa Rica.
BARNHART, T.A. 2005: Ephraim George Squier and the development of American anthropology.- 426 págs., Lincoln, Univ. of Nebraska Press.

CISNEROS, J.C., 2005: New Pleistocene vertebrate fauna from El Salvador.- Rev. Brasil. Paleont. 8: 239-255.

CISNEROS, J.C., 2008: The fossil mammals of El Salvador.- New Mex. Mus. Nat. Hist. Sci. Bull. 44: 375-380.

COPE, E.D., 1884: The extinct Mammalia of the Valley of Mexico.- Proc. Amer. Phil. Soc. 22: 1-21. 
FERRETTI, M.P., 2008: A review of South American proboscideans.- New Mex. Mus. Nat. Hist. Sci. Bull. 44: 381-391.

GERVAIS, P., 1855: Recherches sur les mammifères fossiles d l'Amérique méridionale.- In: CASTELNAU, F.L. (Ed.): Animaux nouveaux ou rares recueillis pendant l'expédition dans les parties centrals d l'Amérique du Sud, de Rio de Janeiro à Lima, et de Lima au Para: Paris: 1-63.

HÉBERT, J.R., 1972: Maps by journalist, scholar and diplomat Ephraim George Squier-Quart. J. Lib. Congr. 29: 14-31.

IBARRA, J.A., 1980: Paleontología en Guatemala.- 52 págs, Guatemala. Editorial "Jose de Pineda Ibarra.

LAURITO, C.A., 1988: Los proboscídeos fósiles de Costa Rica y su contexto en la América Central.- Vínculos, 14: 29-58.

LAURITO, C.A. \& VALERIO, A.L., 2005: First record of Rhynchotherium blicki (Frick, 1933) for the late Cenozoic of Costa Rica.Rev. Geol. Amér. Central, 33: 75-82.

LECONTE, J. 1858: [Mastodon bed in Honduras].Proc. Acad. Nat. Sci. Phila. 10: 7.

LEIDY, J., 1859: [Mastodon tooth from Honduras].Proc. Acad. Nat. Sci. Phila. 11: 91.

LEIDY, J., 1869: The extinct mammalian fauna of Dakota and Nebraska, including an account of some allied forms from other localities, together with a synopsis of the mammalian remains of North America.- J. Acad. Nat. Sci. Phila. 7: 1-472.

LEIDY, J., 1886: Toxodon and other remains from Nicaragua.- Proc. Acad. Nat. Sci. Phil. 1886: 275-277.
LUCAS, S.G., 2008a: Cuvieronius (Mammalia, Proboscidea) from the Neogene of Florida.New Mex. Mus. Nat. Hist. Sci. Bull. 44: 31-38.

LUCAS, S.G., 2008b: Taxonomic nomenclature of Cuvieronius and Haplomastodon, proboscideans from the Plio-Pleistocene of the New World.- New Mex. Mus. Nat. Hist. Sci. Bull. 44: 409-415.

LUCAS, S.G. \& ALVARADO, G.E. 2010: Fossil Proboscidea from the upper Cenozoic of Central America: Taxonomy, evolutionary and paleobiogeographic significance.Rev. Geol.. Amér. Central, 42: 9-42.

LUCAS, S.G. \& MORGAN, G.S., 2008: Taxonomy of Rhynchotherium (Mammalia, Proboscidea) from the Miocene-Pliocene of North America.- New Mex. Mus. Nat. Hist. Sci. Bull. 44: 71-87.

LUCAS, S.G., ALVARADO, G.E. \& VEGA, E., 1997: The Pleistocene mammals of Costa Rica.- J. Vert. Paleont. 17: 413-427.

LUCAS, S.G., GARCÍA, R., ESPINOZA, E., ALVARADO, G.E., HURTADO DE MENDOZA, L. \& VEGA, E., 2008: The fossil mammsl of Nicaragua.- New Mex. Mus. Nat. Hist. Sci. Bull. 44:417-429

LUCAS, S.G., ALVARADO, G.E., GARCÍA, R., ESPINOZA, E., CISNEROS, J.C. \& MARTENS, U., 2007: Vertebrate paleontology.- In: BUNDSCHUH, J. \& ALVARADO, G.E. (Eds): Central America: Geology, resources and hazards. Taylor \& Francis, London: 443-451.

MACFADDEN, B.J., 2006: North American Miocene land mammals from Panama.- J. Vert. Paleont. 26: 720-734.

OSBORN, H. F., 1936: Proboscidea Volume I: Moeritheroidea Deinotheroidea 
Mastodontoidea.- 802 págs., New York, The American Museum Press.

SQUIER, E.G. 1859: A visit to the Guajiquero Indians.- Haper's New Monthly Mag. 19 (113): 602-619.

THOMSON, K. 2008: The legacy of the mastodon: The golden age of fossils in America.- 386 págs, New Haven, Yale University Press.

UDOVIC, R., MORRISON, M. \& HICKERSON, T. 1974: John Melmoth Dow, 1827-1892.40 págs. Papers, 1798-1918. Cornell
University, Department of Manuscripts and Archives.

WARREN, L., 1998: Joseph Leidy: The last man who knew everything.- 303 págs. Yale University Press.

WEBB, S.D. \& PERRIGO, S.C., 1984: Late Cenozoic vertebrates from Honduras and El Salvador.- J. Vert. Paleo. 4: 237-254.

WOODBURNE, M.O., 2010: The great American biotic interchange: dispersals, tectonics, climate, sea level and holding pens.- J. Mammal. Evol. 17: 245-264. 